\title{
PENGARUH APLIKASI PESTISIDA NABATI EKSTRAK RIMPANG KUNYIT, JAHE DAN DAUN SIRIH TERHADAP MORTALITAS KUTU DAUN Aphis sp. PADA TANAMAN CABAI MERAH (Capsicum annuum L.)
}

\section{EFFECT OF BIOPESTISIDES APPLICATION OF TURMERIC RHIZOME, GINGER AND BETEL LEAF EXTRACT ON THE MORTALITY OF Aphis sp. ON RED CHILI PLANTS (Capsicum annuum L.)}

\author{
Lestari Wibowo $^{1}$, Worro Bronto Laras ${ }^{2 *}$, Sudi Pramono ${ }^{2}$ dan Yuyun Fitriana ${ }^{1}$ \\ ${ }^{1}$ Jurusan Proteksi Tanaman, ${ }^{2}$ Jurusan Agroteknologi, Fakultas Pertanian, Universitas Lampung, \\ Bandarlampung, Indonesia \\ *Email: worrobrontolaras11@gmail.com
}

*Corresponding Author, Diterima: 22 Sept. 2021 , Direvisi: 19 Okt. 2021 , Disetujui: 10 Des. 2021

\begin{abstract}
This research was conducted in August-October 2020 at the HPT garden of the Faculty of Agriculture, University of Lampung, which aims to determine the effect of the application of biopestisides (turmeric, ginger and betel leaf) on the mortality of aphids Aphis sp., on chili plants and their effect on the number of leaves. and plant height. This study was arranged using a randomized block design (RAK) with (three treatments of biopestisides, namely turmeric extract application, ginger extract application and betel leaf extract application) and one without biopestisides treatment as a control) and was repeated 4 times. Biopestisides were applied evenly to all experimental plants except control. Observations were made on the mortality of Aphis sp., number of leaves and plant height. Application of biopestisides extracts of turmeric rhizome, ginger rhizome and betel leaf caused the mortality of Aphis sp. respectively by 60\%, 65\%, and 68\% at 5 dsa and significantly different from the control. Application of biopestisides extracts of turmeric rhizome, ginger rhizome and betel leaf for the control of Aphis sp. did not affect plant growth (height and number of leaves) at 7 days of observation.
\end{abstract}

Keywords: Aphis sp., biopestisides.

\begin{abstract}
ABSTRAK
Penelitian ini dilaksanakan pada bulan Agustus-Oktober 2020 bertempat di halaman gedung HPT Fakultas Pertanian Universitas Lampung yang bertujuan untuk mengetahui pengaruh aplikasi pestisida nabati (kunyit, jahe dan daun sirih) terhadap mortalitas kutu daun Aphis sp., pada tanaman cabai dan pengaruhnya terhadap jumlah daun dan tinggi tanaman. Penelitian ini disusun menggunakan rancangan acak kelompok (RAK) dengan (tiga perlakuan pestisida nabati yaitu aplikasi ekstrak kunyit, aplikasi ekstrak jahe dan aplikasi ekstrak daun sirih) dan satu tanpa perlakuan pestisida nabati sebagai kontrol) dan diulang 4 kali. Pestisida nabati diaplikasikan secara merata pada seluruh tanaman percobaan kecuali kontrol. Pengamatan dilakukan terhadap mortalitas Aphis sp., jumlah daun dan tinggi tanaman. Aplikasi pestisida nabati ekstrak rimpang kunyit, rimpang jahe dan daun sirih menyebabkan mortalitas Aphis sp. masing-masing sebesar $60 \%$, 65\%, dan 68\% pada 5 hsa dan secara nyata berbeda dengan kontrol. Aplikasi pestisida nabati ekstrak rimpang kunyit, rimpang jahe dan daun sirih untuk pengendalian Aphis sp. tidak mempengaruhi pertumbuhan tanaman (tinggi dan jumlah daun) pada pengamatan 7 hsa.
\end{abstract}

Kata kunci: Aphis sp., pestisida nabati. 


\section{PENDAHULUAN}

Cabai merah (Capsicum annuum L.) merupakan salah satu jenis sayuran penting yang dibudidayakan secara komersial di daerah tropis. Cabai memiliki kandungan berbagai vitamin, protein dan gula fruktosa. Di Indonesia tanaman ini mempunyai arti ekonomi penting dan menduduki tempat kedua setelah tanaman jenis kacangkacangan (Sibarani, 2008).

Menurut Badan Pusat Statistik (2015) produksi cabai merah segar tahun 2014 sebesar 1,075 juta ton meningkat sebesar 61,74 ribu ton $(6,09 \%)$ dari tahun 2013. Peningkatan produksi cabai tahun 2014 tersebut terjadi di pulau Jawa sebesar 36,06 ribu ton dan luar pulau Jawa sebesar 25,68 ribu ton. Kenaikan ini disebabkan oleh peningkatan luas panen sebesar 4,62 ribu hektar (3,73\%) dibandingkan tahun 2013.

Organisme pengganggu tumbuhan (OPT) baik berupa hama, patogen penyakit maupun gulma yang menjadi faktor pembatas karena dapat menurunkan kuantitas hasil produksi. Permasalahan yang ada pada tanaman cabai merah, tidak hanya terbatas pada masalah budidaya saja, tetapi bagaimana petani mengatasi berbagai macam persoalan tentang cabai yang ditanam. Permasalahan yang umum ditemukan pada tanaman cabai adalah bagaimana mengatasi hama dan penyakit tanaman cabai merah (Setiadi, 2002).

Salah satu hama yang menyerang tanaman cabai merah adalah kutu daun (Aphis sp.). Kutu ini menyerang tangkai bunga ataupun bagian tanaman lain, sehingga daun menjadi belang-belang kekuningan (klorosis) dan akhirnya rontok. Serangan kutu daun terjadinya pada awal musim kemarau, yaitu pada saat udara kering dan suhu tinggi (Setiadi, 2002).

Penggunaan pestisida nabati adalah salah satu cara yang dapat untuk menghindari berbagai dampak negatif yang dapat terjadi akibat penggunaan pestisida sintetis. Pestisida nabati lebih ramah lingkungan dan aman bagi manusia karena terbuat dari bahan yang ada di alam sehingga akan lebih mudah pula terurai di alam (Yudiarti, 2010).

Asmaliyah dkk. (2010) melaporkan bahwa beberapa jenis tumbuhan berpotensi sebagai pestisida nabati mengandung alkaloid, saponin, flavonoid, tanin, polifenol, minyak atsari dan steroid. Pembuatan pestisida nabati dapat dilakukan secara sederhana dengan menggunakan larutan hasil perasan, rendaman, ekstrak, dan rebusan bagian tanaman berupa akar, umbi, batang, daun, biji maupun buah dari tanaman tersebut (Sudarmo, 2009).

Penelitian ini dilakukan bertujuan untuk mengetahui pengaruh aplikasi pestisida nabati (ekstrak kunyit, jahe dan daun sirih) terhadap mortalitas kutu daun Aphis sp. pada tanaman cabai dan pertumbuhan tanaman cabai.

\section{BAHAN DAN METODE}

\subsection{Bahan dan Rancangan Percobaan}

Bahan-bahan yang digunakan adalah rimpang kunyit, jahe, daun sirih, kutu daun (kutu Aphis sp.), tanah, pupuk kandang, benih cabai, dan air. Penelitian ini disusun menggunakan Rancangan Acak Kelompok (RAK) dengan perlakuan yaitu $\mathrm{P} 0=$ Kontrol (tanpa aplikasi pestisida nabati); P1 = Aplikasi pestisida nabati ekstrak kunyit; P2 = Aplikasi pestisida nabati ekstrak jahe; $\mathrm{P} 3=$ Aplikasi pestisida nabati ekstrak daun sirih. Seluruh perlakuan diulang sebanyak tiga kali.

\subsection{Persiapan Media Tanam}

Penyemaian benih cabai dilakukan di atas nampan semai dengan menggunakan tanah dan kompos. Penyemaian dilakukan dengan waktu semai selama 14 hari. Setelah itu hasil semai dipindahkan ke polybag sebanyak 16 polybag, setiap satuan percobaan berisi satu tanaman. Setelah itu persiapan tanah dan pupuk kandang yang sudah dihomogenkan sebagai media tanam dengan perbandingan $2: 1$. Tanah dan pupuk kandang tersebut dimasukkan ke dalam polybag 10 $\mathrm{kg}$, kemudian tanaman cabai ditanam tanpa membawa tanah dari media tanam awal.

\subsection{Pemeliharaan Tanaman}

\subsubsection{Penyiraman}

Penyiraman tanaman cabai merah dilakukan setiap 1 hari dua kali (pagi dan sore). Penyiraman dilakukan pada setiap polybag yang belum sampai kering secara merata agar lingkungan pada masingmasing polybag percobaan tetap lembab, tetapi polybag percobaan tidak boleh tergenang air.

\subsubsection{Penyiangan}

Penyiangan gulma dilakukan satu kali seminggu dan tergantung pada pertumbuhan gulmanya. Penyiangan dilakukan secara manual dengan cara 
mencabut gulma. Saat melakukan penyiangan diusahakan jangan sampai merusak perakaran tanaman, karena akar tanaman sangat penting dalam penyerapan unsur hara.

\subsection{Pembuatan Pestisida Nabati}

Pestisida nabati yang digunakan dalam penelitian ini terdiri dari ekstrak rimpang kunyit, ekstrak rimpang jahe dan ekstrak daun sirih. Selanjutnya bahan yang digunakan ditimbang seberat $200 \mathrm{~g}$. Masing-masing bahan dihaluskan menggunakan blender, lalu diberi air sebanyak 1000 ml. Kemudian ekstrak disimpan selama satu malam. Setelah itu dilakukan penyaringan terhadap masingmasing ekstrak dengan menggunakan kain kasa. Keesokan harinya ekstrak pestisida nabati siap untuk digunakan.

\subsection{Aplikasi Pestisida Nabati}

Aplikasi ekstrak pestisida nabati dilakukan pada pagi hari pukul 07.00-08.00 WIB. Aplikasi dilakukan dengan cara menyemprotkan cairan pestisida nabati sesuai perlakuan pada tanaman cabai secara merata. Jumlah cairan pestisida nabati yang diaplikasikan yaitu sebanyak $10 \mathrm{ml} /$ tanaman.

\subsection{Investasi Aphis sp.}

Investasi dilakukan dengan cara mengambil Aphis sp. dari tanaman yang sudah terserang menggunakan kuas kecil. Selanjutnya, dimasukkan ke dalam wadah mangkuk, lalu diletakkan pada masing-masing tanaman yang akan diuji sebanyak 25 ekor Aphis sp./tanaman.

\subsection{Parameter Pengamatan}

\subsubsection{Mortalitas Kutu Daun}

Mortalitas kutu dilakukan dengan cara dilakukan pengamatan 3 jsa, 6 jsa, dan 9 jsa. Keesokan harinya pengamatan dilakukan pada pukul 17.00 WIB selama 5 hari pengamatan. Menggunakan rumus (Nindatu, 2016):

$$
\mathrm{M}=(\mathrm{a} / \mathrm{b}) \times 100 \%
$$

Dimana $\mathrm{M}=$ Presentase mortalitas (\%); $\mathrm{a}=$ jumlah nimfa yang mati; $b=$ jumlah nimfa yang digunakan

\subsubsection{Tinggi tanaman}

Tinggi tanaman diukur menggunakan meteran dengan cara mengukur dari pangkal tanaman sampai pada daun yang paling tinggi (monokotil) dan sampai titik tumbuh (dikotil). Pengamatan dilakukan pada saat aplikasi pestisida nabati dan satu minggu setelah aplikasi pestisida nabati.

\subsubsection{Jumlah daun}

Penghitungan jumlah daun dilakukan dengan cara menghitung jumlah daun pada setiap tanaman. Pengamatan jumlah daun dilakukan sebanyak 3 kali yaitu pada saat satu minggu sebelum aplikasi, saat aplikasi dan satu minggu setelah aplikasi pestisida nabati. Daun yang dihitung meliputi daun yang sudah membuka dan lengkap bagian-bagiannya.

\subsubsection{Analisis data}

Homogenitas hasil penelitian dilakukan dengan uji barlet dan addivitas data dengan uji tukey. Setelah itu, dilakukan analisis ragam, jika beda nyata dilakukan uji beda nyata terkecil (BNT) pada taraf 5\%.

\section{HASIL DAN PEMBAHASAN}

\subsection{Mortalitas Aphis sp.}

Dari hasil penelitian diketahui bahwa aplikasi ekstrak rimpang kunyit, jahe, dan daun sirih secara nyata dapat menyebabkan mortalitas Aphis sp. Data mortalitas Aphis sp. tertera pada Tabel 1.

Pada pengamatan selama 6 dan 9 jsa terlihat mortalitas Aphis sp. meningkat. Pada pengamatan 9 jsa, mortalitas Aphis sp. pada perlakuan aplikasi ekstrak kunyit, jahe, dan daun sirih secara nyata berbeda dengan kontrol. Pada perlakuan aplikasi ekstrak rimpang jahe mortalitas Aphis sp. tertinggi yaitu $26 \%$ berbeda dengan perlakuan lainnya. Pada perlakuan aplikasi ekstrak kunyit mortalitas Aphis sp. yaitu $12 \%$ dan aplikasi ekstrak daun sirih yaitu $20 \%$.

Selanjutnya pengamatan dilakukan setiap 24 jam, yaitu pada sore hari. Dari hasil pengamatan mortalitas Aphis sp. terus meningkat sampai dengan hari kelima setelah aplikasi. Pada pengamatan 6 hsa, jumlah Aphis sp. meningkat karena adanya kelahiran dari Aphis sp. yang bisa bertahan hidup.

Dari Tabel 2 terlihat bahwa bahwa aplikasi tiga ekstrak pada 5 hsa mampu menyebabkan mortalitas Aphis sp. hingga diatas 50\%. Aplikasi rimpang jahe, 
Tabel 1. Persentase Mortalitas Aphis sp. akibat Aplikasi Ekstrak Rimpang Kunyit, Jahe, dan Daun Sirih pada 3, 6, dan 9 Jam Setelah Aplikasi (JSA).

\begin{tabular}{cccc}
\hline \multirow{2}{*}{ Perlakuan } & \multicolumn{3}{c}{ Mortalitas $(\%)$} \\
\cline { 2 - 4 } & 3 jsa & 6 jsa & 9 jsa \\
\hline P0 & $0 \mathrm{a}$ & $0 \mathrm{a}$ & $0 \mathrm{a}$ \\
P1 & $2 \mathrm{a}$ & $7 \mathrm{ab}$ & $12 \mathrm{~b}$ \\
P2 & $12 \mathrm{~b}$ & $19 \mathrm{c}$ & $26 \mathrm{~d}$ \\
P3 & $4 \mathrm{a}$ & $14 \mathrm{bc}$ & $20 \mathrm{c}$ \\
\hline F Tabel & 3,86 & 3,86 & 3,86 \\
\hline F Hitung & $9,22^{*}$ & $8,58^{*}$ & $59,84^{*}$ \\
\hline
\end{tabular}

Tabel 2. Persentase Mortalitas Aphis sp. akibat Aplikasi Ekstrak Rimpang Kencur, Jahe dan Daun sirih pada 2, 3, 4 dan 5 Hari Setelah Aplikasi (HSA).

\begin{tabular}{|c|c|c|c|c|c|c|c|c|}
\hline \multirow{3}{*}{$\begin{array}{c}\text { Perlakuan } \\
\text { P0 }\end{array}$} & \multicolumn{8}{|c|}{ Mortalitas (\%) } \\
\hline & \multicolumn{2}{|c|}{$2 \mathrm{hsa}$} & \multicolumn{2}{|c|}{$3 \mathrm{hsa}$} & \multicolumn{2}{|c|}{$4 \mathrm{hsa}$} & \multicolumn{2}{|c|}{$5 \mathrm{hsa}$} \\
\hline & 0 & $\mathrm{a}$ & 0 & $\mathrm{a}$ & 0 & $\mathrm{a}$ & 0 & $\mathrm{a}$ \\
\hline P1 & 18 & $\mathrm{~b}$ & 37 & $\mathrm{~b}$ & 49 & $\mathrm{~b}$ & 60 & $\mathrm{~b}$ \\
\hline P2 & 28 & $\mathrm{~b}$ & 42 & $\mathrm{~b}$ & 53 & $\mathrm{~b}$ & 65 & $\mathrm{~b}$ \\
\hline P3 & 26 & $\mathrm{~b}$ & 39 & $\mathrm{~b}$ & 51 & $\mathrm{~b}$ & 68 & b \\
\hline F Tabel & \multicolumn{2}{|c|}{3,86} & \multicolumn{2}{|c|}{3,86} & \multicolumn{2}{|c|}{3,86} & \multicolumn{2}{|c|}{3,86} \\
\hline F Hitung & \multicolumn{2}{|c|}{$24,50 *$} & \multicolumn{2}{|c|}{$13,42 *$} & \multicolumn{2}{|c|}{$32,77^{*}$} & \multicolumn{2}{|c|}{$81,18^{*}$} \\
\hline
\end{tabular}

Tabel 3. Rata-rata Tinggi Tanaman Cabai pada Setiap Perlakuan.

\begin{tabular}{cccc}
\hline \multirow{2}{*}{ Perlakuan } & \multicolumn{2}{c}{ Tinggi Tanaman $(\mathrm{cm})$} & $\begin{array}{c}\text { Rata-rata pertambahan } \\
\text { tinggi tanaman }(\mathrm{cm})\end{array}$ \\
\cline { 2 - 3 } & $0 \mathrm{msa}$ & $1 \mathrm{msa}$ & $5,00 \mathrm{a}$ \\
P0 & $26,25 \mathrm{a}$ & $31,25 \mathrm{a}$ & $4,50 \mathrm{a}$ \\
P1 & $26,50 \mathrm{a}$ & $31,00 \mathrm{a}$ & $3,25 \mathrm{a}$ \\
P2 & $24,75 \mathrm{a}$ & $28,00 \mathrm{a}$ & $5,00 \mathrm{a}$ \\
\hline P Tabel & $36,25 \mathrm{~b}$ & $41,25 \mathrm{~b}$ & 3,86 \\
\hline F Hitung & 3,86 & 3,86 & $3,74^{\mathrm{tn}}$ \\
\hline
\end{tabular}

rimpang kunyit dan daun sirih tidak berbeda nyata pada taraf uji BNT 5\%.

Dari Gambar 1 dapat dilihat bahwa selama 5 hari pengamatan pada aplikasi ekstrak rimpang kunyit, rimpang jahe dan daun sirih populasi Aphis sp. menurun karena adanya kematian akibat aplikasi pestisida nabati. Sedangkan pada kontrol populasi Aphis sp. meningkat karena adanya perkembangbiakan sehingga pada hari ke 5 populasi Aphis sp. mencapai 45 ekor/tanaman.

Dari Gambar 2 terlihat bahwa pada penelitian ini perlakuan P0 (kontrol) tidak diberikan perlakuan aplikasi pestisida nabati, sehingga populasi kutu tersebut meningkat, daun cabai menggulung dan daun muda tanaman cabai tersebut selanjutnya menguning dan gugur. Pada tanaman dengan perlakuan aplikasi pestisida nabati (P1, P2, dan P3) tanaman dapat tumbuh dengan baik.
Dari Gambar 2 keriting daun cabai adalah salah satu keadaan yang menjadi keriting, kuning, kurus, dan rontok. Keadaan daun seperti ini menyebabkan nutrisi tidak bisa diproses secara sempurna, tanaman tidak bertumbuh lebat, produktifitas tanaman menurun dan pada kasus terparah bisa terjadi gagal panen. Banyak faktor yang dapat menyebabkan keriting daun pada tanaman cabai, salah satunya yaitu serangan hama atau disebut juga OPT. Ada beberapa beberapa jenis hama yang dapat menyebabkan keriting daun ini. Salah satu hama yang dapat menyebabkan terjadinya keriting pada daun cabai ialah Aphis sp.

\subsection{Tinggi Tanaman}

Pengamatan tinggi tanaman dilakukan sebelum aplikasi pestisida nabati dan 7 hari setelah aplikasi 


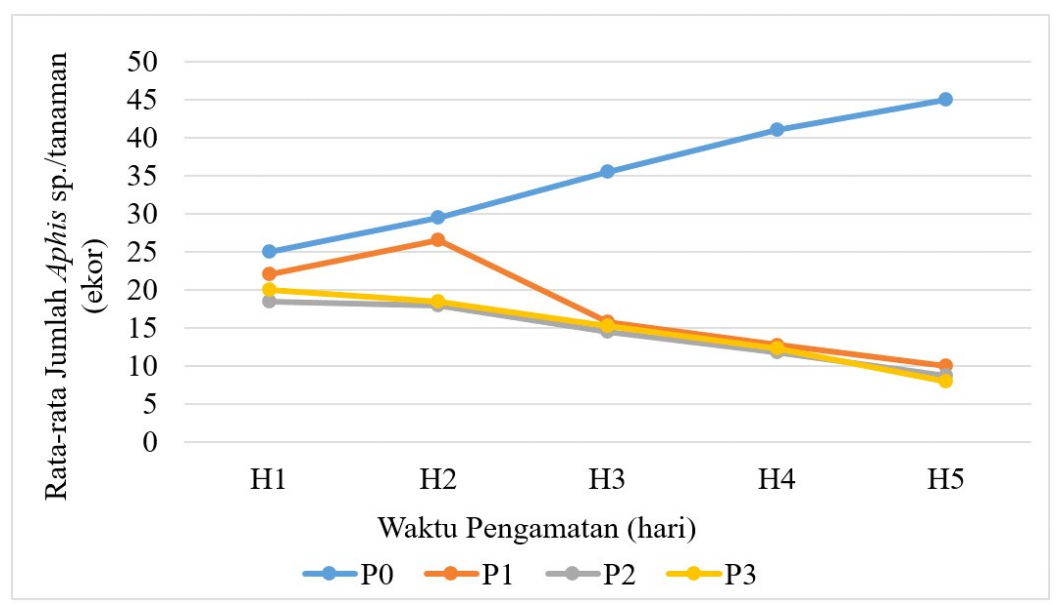

Gambar 1. Rata-rata Jumlah Aphis sp. (Ekor/Tanaman) pada Perlakuan Aplikasi Ekstrak Rimpang Kunyit, Jahe, dan Daun Sirih, yang Hidup dari Hari Pertama Sampai Hari Kelima pada Jam Terakhir Pengamatan.
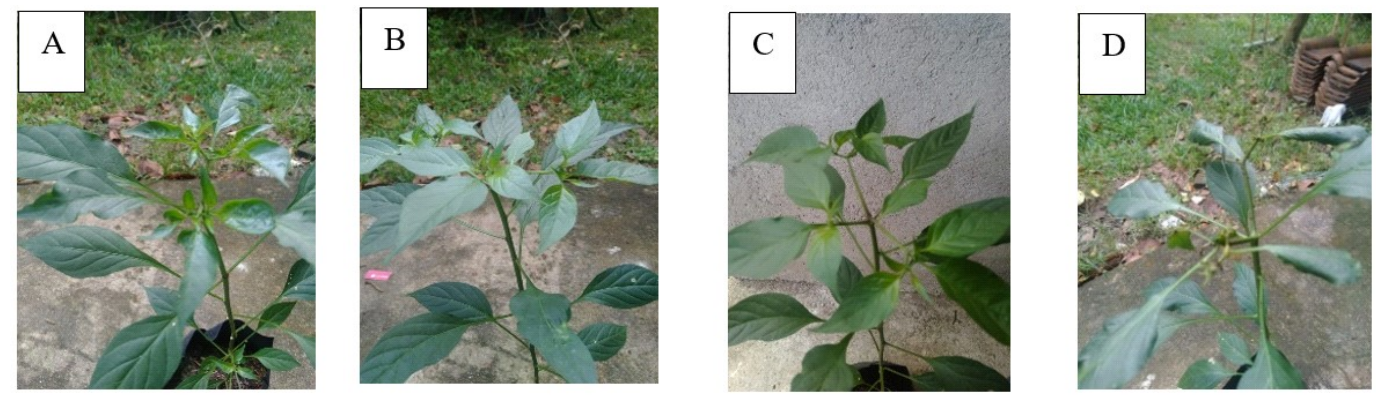

Gambar 2. Pertumbuhan Cabai Merah yang Diinvestasikan Kutu Daun dengan Perlakuan Aplikasi Pestisida Nabati dan Tanpa Aplikasi Pestisida Nabati (P0).

(hsa) pestisida nabati. Hasil analisis statistik menunjukkan bahwa semua perlakuan tidak berpengaruh terhadap pertambahan tinggi tanaman. Data rata-rata tinggi tanaman dan data pertambahan tinggi tanaman pada Tabel 3.

\subsection{Jumlah Daun}

Hasil analisis statistik menunjukkan bahwa pengamatan $-7 \mathrm{hsa}, 0$ hsa $\& 7 \mathrm{hsa}$, seluruh perlakuan tidak mempengaruhi jumlah daun. Data jumlah daun dapat dilihat pada Tabel 4.

\subsection{Pembahasan}

Dari hasil penelitian ini diketahui bahwa aplikasi ekstrak rimpang kunyit, jahe, dan daun sirih secara nyata menyebabkan mortalitas kutu Aphis sp. pada pengamatan 5 hsa aplikasi ekstrak daun sirih menyebabkan mortalitas kutu Aphis sp. 68\% secara nyata berbeda dengan kontrol. Mortalitas Aphis sp. pada perlakuan aplikasi ekstrak rimpang kunyit dan rimpang jahe masing-masing $60 \%$ dan $65 \%$ dimana nilai tersebut tidak berbeda nyata antar perlakuan aplikasi ekstrak rimpang kunyit, jahe dan daun sirih. Tingkat kematian Aphis sp. akibat aplikasi ekstrak rimpang kunyit, jahe, dan daun sirih di atas $60 \%$ menunjukkan bahwa pestisida nabati ekstrak rimpang kunyit, jahe, dan daun sirih dapat dikatakan efektif. Agar mortalitas lebih tinggi lagi maka aplikasi dapat dilakukan beberapa kali. Ekstrak rimpang jahe pada konsentrasi 20\% dapat menyebabkan kematian walang sangit sebesar 92\% (Yuandita, 2018). Sedangkan ekstrak daun sirih menyebabkan kematian pada walang sangit (Leptocorisa acuta) sebesar 60\% (Yunianti, 2016) dan Sithopilus zeamais M. sebesar 75\% (Harahap dan Rakhmadiah, 2016).

Pada ekstrak rimpang kunyit beberapa senyawa yang diduga berperan terhadap kematian Aphis sp. yaitu: senyawa flavonoid, steroid dan minyak atsirih. Iftiah (2016), menyatakan bahwa flavonoid berfungsi sebagai racun pernapasan sehingga saat Aphis sp. melakukan pernapasan 
Tabel 4. Rata-rata Jumlah Daun Tanaman Cabai pada Setiap Perlakuan.

\begin{tabular}{cccc}
\hline \multirow{2}{*}{ Perlakuan } & \multicolumn{3}{c}{ Jumlah daun } \\
\cline { 2 - 4 } & -7 hsa & 0 hsa & 7 hsa \\
\hline P0 & 12,00 & 16,25 & 20,25 \\
P1 & 12,25 & 16,00 & 20,25 \\
P2 & 13,50 & 16,75 & 21,25 \\
P3 & 14,00 & 17,75 & 21,75 \\
\hline F Tabel & 3,86 & 3,86 & 3,86 \\
\hline F Hitung & $1,52^{\text {th }}$ & $0,49^{\text {th }}$ & $0,42^{\text {th }}$ \\
\hline
\end{tabular}

akan terganggu. Steroid bekerja sebagai racun syaraf (Hidana dan Novia, 2015). Sedangkan minyak atsirih bekerja sebagai racun kontak (Adityo dkk., 2013).

Mekanisme kematian Aphis sp. pada perlakuan ekstrak rimpang jahe diperkirakan karena kandungan senyawa kaemferol, saponin dan flaponoid. Senyawa kaemferol dan flavonoid yang terkandung di dalam jahe memiliki pengaruh sebagai inhibitor pernafasan kuat bagi serangga sehingga sistem pernafasan serangga menjadi terganggu, sedangkan saponin mengakibatkan menurunkan nafsu makan (Suadnyani, 2016).

Tingkat kematian pada Aphis sp. akibat diaplikasikannya ekstrak daun sirih ini dapat disebabkan karena kandungan senyawa yang terdapat didalamnya. Beberapa senyawa ekstrak daun sirih yang berpotensi sebagai insektida alami seperti tanin, fenol, alkaloid, dan minyak atsirih. Menurut Yunita dkk. (2009), tanin juga dapat mengganggu serangga dalam mencerna makanan. Senyawa alkaloid yang terkadung di dalam ekstrak daun sirih dapat berfungsi sebagai racun perut bagi serangga hama (Cania dan Setyaningrum, 2013).

Pada pengamatan tinggi tanaman dan jumlah daun tidak terjadi perbedaan hasil. Hasil analisis statistik tinggi tanaman menunjukkan bahwa seluruh perlakuan yang digunakan tidak berpengaruh terhadap pertambahan tinggi tanaman cabai. Pada hasil analisis statistik jumlah daun juga menunjukkan bahwa seluruh perlakuan yang digunakan tidak berpengaruh terhadap pertambahan jumlah daun tanaman cabai.

\section{KESIMPULAN}

Aplikasi pestisida nabati ekstrak rimpang kunyit, rimpang jahe dan daun sirih menyebabkan mortalitas Aphis sp. masing-masing sebesar 60\%, $65 \%$ dan $68 \%$ pada 5 hsa dan secara nyata berbeda dengan kontrol. Aplikasi pestisida nabati ekstrak rimpang kunyit, rimpang jahe dan daun sirih untuk pengendalian Aphis sp. tidak mempengaruhi pertumbuhan tanaman (tinggi dan jumlah daun) pada pengamatan $7 \mathrm{hsa}$

\section{DAFTAR PUSTAKA}

Adityo, R.H.P.P., Kurniawan, B., dan Mustofa S. 2013. Uji efek fraksi ekstrak batang Kecombarang (Etlingera elatior) sebagai larvasida terhadap larva Instar III Aedes aegypti. Skripsi. Universitas Lampung, Lampung.

Asmaliyah, Wati, E.E.H., Utami., Mulyadi, S., Yudhistira, K., dan Sari.F.W. 2010. Pengenalan Tumbuhan Penghasil Pestisida Nabati dan Pemanfaatannya Secara Tradisonal. Badan Penelitian dan Pengembangan Kehutanan. Palembang.

Badan Pusat Statistik. 2015. Produksi Cabai Besar, Cabai Rawit dan Bawang Merah Tahun 2014. Berita Resmi Statistik BPS Sumatera Barat.www.bps.go.id, Tanggal Akses : 21 September 2019.

Cania, B. dan Setyaningrum, E. 2013. Uji efektifitas larvasida ekstrak daun legundi (Vitex trifolia) terhadap mortalitas larva Aedes aegypti. Skripsi. Universitas Lampung. Lampung.

Harahap dan Rakhmadiah, K. 2016. Uji beberapa konsentrasi tepung daun sirih hutan (Piper aduncum L.) untuk mengendalikan hama Sitophilus zeamais M. pada biji jagung di penyimpanan. Jurnal Agroekotek. 8 (2) : 82-94.

Hidana, R. dan Novia, S. 2015. Efektivitas ekstrak daun Sereh (Cymbopogon nardus) sebagai antioviposisi terhadap nyamuk Aedes aegypti. Jurnal Kesehatan Bakti Tunas Husada. 13(1):133-138.

Iftitah, I. 2016. Uji efektivitas rendaman daun Singkong (Manihot utilissima) sebagai insektisida terhadap nyamuk Aedes aegypti dengan metode elektrik cair. Jurnal Kesehatan Masyarakat. 4(2): 5-6. 
Nindatu. 2016. Efektifitas ekstrak cabai merah (Capsicum annum L) terhadap mortalitas kutu daun (Aphis gossypli) pada tanaman cabai. Jurnal Agrologia. 5(1): 10-14.

Setiadi. 2002. Bertanam Cabai. Penebar Swadaya. Jakarta.

Sibarani. 2008. Uji efektifitas beberapa fungisida nabati untuk mengendalikan penyakit antraknosa (Colletrotichum capsici) pada tanaman cabai (Capsicum annuum L.) di Lapangan. Skripsi. Universitas Sumatera Utara: Medan. 54.

Suadnyani, A. A. I. 2016. Pengaruh konsentrasi ekstrak etanol rimpang jahe merah (Zingiber officinale Rosc) terhadap kematian larva nyamuk Aedes aegypti. Jurnal Medika. 5 (8).

Sudarmo. 2009. Pestisida Nabati: Pembuatan dan Pemanfaatannya. Kanisius. Yogyakarta.
Yuandita, E. 2018. Pengaruh variasi konsentrasi ekstrak rimpang jahe (Zingiber officinale Rosc) sebagai insektisida alami terhadap mortalitas walang sangit (Leptocorisa oratorius F). Skripsi. Universitas Islam Negeri Mataram. Mataram.

Yudiarti. 2010. Ilmu Penyakit Tumbuhan. Graha Ilmu.Yogyakarta.

Yunianti L. 2016. Uji efektivitas ekstrak daun sirih hijau (Piper betle) sebagai insektisida alami terhadapa mortalitas walang sangit (Leptocorisa acuta). Skripsi. Universitas Sanata Dharma Yogyakarta. Yogyakarta.

Yunita, E.A.N.H., Suprapti, J.S., dan Hidayat. 2009. Ekstrak daun teklan (Eupatorium riparium) terhadap mortalitas dan perkembangan larva Aedes aegypti. Bioma. 11(1): 11-17. 